\title{
A CSR egyik lehetséges jövője, a társadalmi vállalkozó és a társadalmi vállalkozói attitứd mérése
}

\author{
Putzer Petra - Bányai Edit \\ Pécsi Tudományegyetem
}

\begin{abstract}
A TANULMÁNY CÉLJA
A CSR napjainkban egyre divatosabb kifejezéssé válik, ám ezzel együtt egyre több esetben derül ki, hogy a felelős tevékenység mögött nem a 'társadalmi jó' szolgálata áll, hanem egyszerüen csak új marketingeszköznek tekintik a vállalatok. Ugyanakkor a társadalmi vállalkozók megjelenésével egy lehetséges új jövőkép is körvonalazódni látszik a valódi felelősségvállalás kapcsán. A tanulmány célja kettős, egyfelől a társadalmi vállalkozó fogalmának bemutatása és annak a CSR keretrendszerében való értelmezése, majd ezt követően a társadalmi vállalkozói attitűd mérésére szolgáló eszköz kialakítása.
\end{abstract}

\begin{abstract}
ALKALMAZOTT MÓDSZERTAN
A tanulmány tisztázza a társadalmi vállalkozás és vállalkozó fogalmát és vizsgálja a társadalmi vállalkozások vállalkozói spektrumon elfoglalt helyét. Ezek alapján került meghatározásra, hogy a társadalmi vállalkozói attitűd mérésekor milyen aspektusokat veszünk számításba. A mérésre alkalmas kérdőív kidolgozása szekunder kutatás segítségével történt, amely a három fő kérdésblokk (vállalkozói attitűd, társadalmi érzékenység, CSR attitüd) esetében alkalmazott és validált skálák feltárását és integrálását foglalja magában.
\end{abstract}

\section{LEGFONTOSABB EREDMÉNYEK}

Úgy tünik, hogy a vállalkozók új generációja mentheti meg a CSR koncepciót, ám ennek mérésére szolgáló elfogadott kérdőív nem létezett. E vállalkozói szándék és attitüd mérését lehetővé tevő kérdőív összeállítása történt meg a tanulmányban. Ennek eredményeképp pedig célunk a létrehozott skála validálása, annak vizsgálata, hogy a három fő blokk mindegyike valóban jó közelítéssel méri a társadalmi vállalkozói attitüdöt elsősorban egyetemisták körében.

\section{GYAKORLATI JAVASLATOK}

Kutatásunk hazai és nemzetközi szinten is hiánypótló, eredményei alapját adják további kutatásoknak a társadalmi vállalkozások mélyebb megértése céljából. A következő lépésben pedig szükséges a kérdőív tesztelése, amelyet a cikk megírását követően el is kezdtünk.

Kulcsszavak: társadalmi vállalkozó, vállalkozói attitüd, társadalmi érzékenység, CSR attitűd

DOI: https://doi.org/10.15170/MM.2019.53.EMOK.02 


\section{BEVEZETÉS}

A CSR napjainkban egyre divatosabb kifejezéssé válik, ám ezzel együtt egyre több esetben derül ki, hogy a felelös vagy annak tünő tevékenység mögött nem a 'társadalmi jó' szolgálata áll, hanem egyszerüen csak új marketingeszköznek tekintik a vállalatok, amit érdemes használni. A felelősségvállalásnak ráadásul számos szintje különböztethető meg a felszínes, ráépülő (bolt-on) típusú tevékenységektől a valódi mély felelősségvállalásig, vagyis a beépült (built-in) megoldásokig. A magyar vállalatok CSR-rel kapcsolatos motivációja és az attitủdjük inkább a felszínes, nem is annyira felelős tevékenységeknek kedvez. A vállalatokat négy fö tényező motiválja a CSR tevékenységek során: a kommunikációs érték, az érintett csoportok meggyőzése, a pénzügyi előnyök és az altruizmus, vagyis többnyire külső nyomás hatására kezdenek el ilyen akciókat végrehajtani, s leginkább a felszínes, olcsóbb tevékenységeket választják (Putzer - Csapi 2018).

Miközben a CSR kezd egyre többször negatív színezetet kapni, a társadalmi vállalkozók vagy divatosabb nevükön „social entrepreneur”-ök, az üzleti vállalkozások, illetve vállalkozók új generációja mentheti meg a CSR koncepciót. A társadalmi vállalkozók megjelenésével egy lehetséges új jövőkép is körvonalazódni látszik a valódi felelősségvállalás kapcsán.

A tanulmány célja kettős, egyfelől a társadalmi vállalkozó fogalmának bemutatása és annak a CSR keretrendszerében való értelmezése, majd ezt követően a társadalmi vállalkozói attitűd mérése, illetve az ezt lehetővé tévő kérdőív kidolgozása a szakirodalmi sztenderdek mentén a vállalkozói attitűd, a társadalmi érzékenység és a CSR attitűd mentén.

\section{A CSR CSÚCSA, A TÁRSADALMI VÁLLALKOZÓ}

Miért jelentheti a társadalmi vállalkozó a CSR megmenekülését? A kérdés megválaszolásához először áttekintjük a fogalmat. Chell (2007) általános definíciót ad, amely szerint a társadalmi vállalkozók olyan tevékenységeket folytatnak, amely társadalmi misszióval, céllal, vagy értékkel bír, majd pontosítva az eredeti definíciót, Chell et al. (2010) úgy írja le a társadalmi vállalkozót, mint társadalmi céllal bíró innovatív tevékenységet végző szereplöt, akár for-profit, akár CSR, akár nonprofit területen valósul meg.
Nem elegendő azonban csupán a felelös célt szolgálni, mindezt úgy kell tenni, hogy közben a tevékenység gazdaságilag is jövedelmezö lehessen, hiszen csak így lehetséges a cél folyamatos kiszolgálása, ezért Di Domenico et al. (2010) a társadalmi cél szolgálatán túl meghatározásába foglalja a pénzügyi fenntarthatóságot is. Thompson (2002), valamint Cheney és Roper (2005) korábban ezt úgy fogalmazták meg, mint a for-profit és nonprofit mellett kialakuló harmadik, not-for-profit típust, vagyis a társadalmi vállalkozó kitűnően ötvözi a nonprofit szervezetekre jellemző társadalmi célorientáltságot és a for-profit vállalkozások gazdasági szemléletét. Vagyis például hiába gondolja magát valamilyen NGO társadalmi vállalkozásnak, ha a piaci alapon való gondolkodás hiányában képtelen a termékét/szolgáltatását eladni. Ugyan elsősorban CSR szempontból, de Lukács (2015) különleges szimbiózist, lényegében társadalmi vállalkozást elemez cikkében, a választott Szatyor Egyesület és Szatyorbolt szervezet ugyanis jól szemlélteti, miképp müködhet egy nonprofit egyesületből és egy üzleti vállalkozásból álló speciális szervezet.

Timár (2014) is kiemeli, hogy sikeres társadalmi vállalkozás elengedhetetlen részei a megfelelő üzleti modell és vállalkozói kompetenciák. Elöbbi azért is fontos, mert nem minden szervezeti megoldás, müködési forma képes a társadalmi értéket teremteni és nem minden érték kinyerését célzó stratégia szolgál társadalmi célokat, azonban megfelelő esetben a társadalmi vállalkozás az, amely képes olyan érték teremtésére és kinyerésére, amely a társadalmi célokat szolgálja (Agafonow 2014).

Az Európai Bizottság (2011) pedig az alábbi módon határozza meg a társadalmi vállalkozást:

- gazdasági tevékenysége valamilyen társadalmi célt is szolgál, gyakran a magas szintủ társadalmi innováció formájában,

- nyeresége jelentős részét visszaforgatja e szociális cél elérése érdekében,

- demokratikus vagy részvételi alapelvü müködés, vagy a társadalmi igazságosság célkitüzésein nyugvó felépítés vagy tulajdonlás jellemzi.

A social entrepreneur típusú vállalkozók, vállalatok tehát a szocioökonómiai hatásukra koncentrálnak, ami megfelelően adja vissza a mélyebb típusú CSR felelős „doing well by doing good” alapgondolatát. Ennek alapján ugyanis ezek a szereplök a klasszikus üzleti vállalkozásokhoz hasonlóan pénzügyileg önfenntartóak, azonban elsődleges céljuk nem a profitmaximalizálás, hanem társadalmi változások stimulálása, társadalmi cél megvalósítása a tevékenységük révén. 
Úgy képzelhető el, mint a CSR és a társadalmi marketingmodell eleminek (lásd Piskóti 2012) speciális kombinációja. Összefoglalásként az eddig bemuta- tott vállalkozói spektrumot és a társadalmi vállalkozások határát szemlélteti az alábbi 1. ábra.

\section{1. ábra: Vállalkozások spektruma és a társadalmi vállalkozások határai}

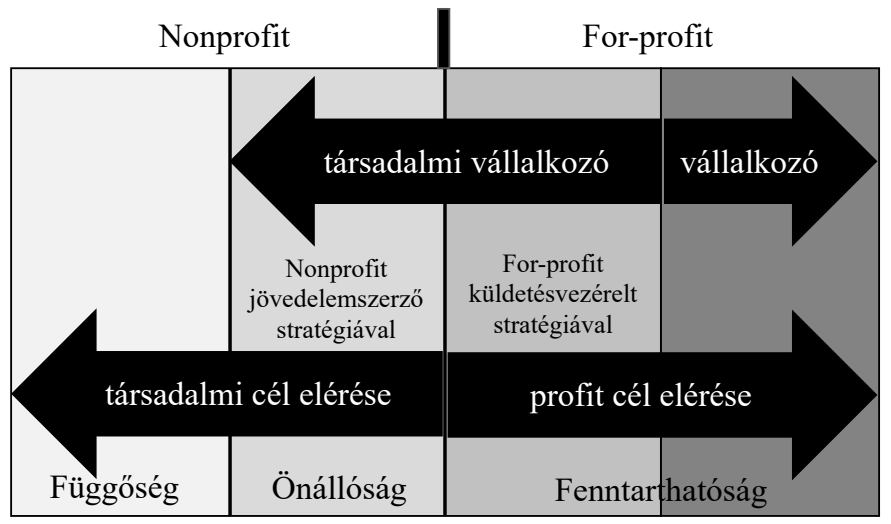

Forrás: Abu-Saifan $(2012,26)$

Carroll elméletének megfelelően egyszerre szolgálják, egyensúlyozzák ki a gazdasági, társadalmi és környezeti értékeket saját maguk és stakeholdereik számára is (Cholette et al. 2014), s ennek megfelelően Nicolopoulou (2014) amellett érvel, hogy a társadalmi vállalkozó koncepciója a CSR egy speciális területe. Ráadásul számos start-up ma már eleve CSR misszióval is bír indulásakor, felelős-orientáltság jellemzi őket (Cholette et al. 2014). Ugyanis azon túl, hogy jövedelmezö üzletet, for-profit vállalkozást szeretnének, már az induláskor megfogalmazódik bennük, hogy mindezt valamilyen társadalmi cél szolgálatával tegyék, akár felelős termékek, szolgáltatások nyújtása révén, ily módon tehát a társadalmi vállalkozó és a társadalmi vállalkozás a CSR legintegráltabb formáját és egyúttal a CSR piramis csúcsát is jelenti.

A fogalmi tisztázást követően érdemes arra is kitérni, hogy mi jellemzi a társadalmi vállalkozókat, hiszen a társadalmi vállalkozói attitúd méréséhez fontos ezek megállapítása. Dees (1998) ezeket a jellemzőket az alábbi 5 pontban foglalja: küldetése nem csak saját, hanem társadalmi érték létrehozása és fenntartása; az előbbi küldetést szolgáló újabb és újabb lehetőségek folyamatos figyelése és alkalmazása; elkötelezett a folyamatos innováció, alkalmazkodás és tanulás mellett, tudatosan/határozottan cselekszik, nem engedi, hogy rendelkezésére álló erőforrásai korlátozzák és transzparensen müködik, vagyis fokozottan ügyel a tevékenysége átláthatóságára, elszámoltatható és bemutatja az általa generált eredményeket.

Basdekidou (2017) is kiemeli, hogy a személyes értékek szerepe fontos hajtóerő e terület esetében gazdasági, társadalmi, pszichológiai és politikai katalizátorok mellett. A társadalmi vállalkozók vagy a társadalmi vállalkozások vezetői egyszerre innovátorok, vagyis keresik az újabb lehetőségeket és társadalmilag érzékenyek, társadalmi értéket teremtenek (Cheney \& Roper 2005, Abu-Saifan 2012).

Fontos továbbá az is, hogy az üzleti szemlélet integrálása mellett a társadalmi vállalkozók csoportja szerepvállalásában is eltér, akár a társadalmi jóért küzdő aktivistáktól, akár a társadalmi ügyeket szolgáló NGO-któl. A 2. ábrán látható, hogy a szociális szolgáltatóként definiált csoporthoz hasonlóan közvetlenül cselekednek, vagyis nem mások meggyőzésén, befolyásolásán keresztül igyekeznek hatni, mint az aktivisták csoportja. Azonban míg a szociális szolgáltató jelegü szervezetek a meglévő rendszer fenntartásán és javításán dolgoznak (például afrikai árvák számára iskolák építése az iskolázottság növelése érdekében), hasonlóan az aktivista csoporthoz, a társadalmi vállalkozók egy új egyensúly megteremtésére, új rendszer kiépítésére és fenntartására törekednek (Martin \& Osberg 2007), amely ismételten mutatja az innovatív gondolkodásmódjukat. 


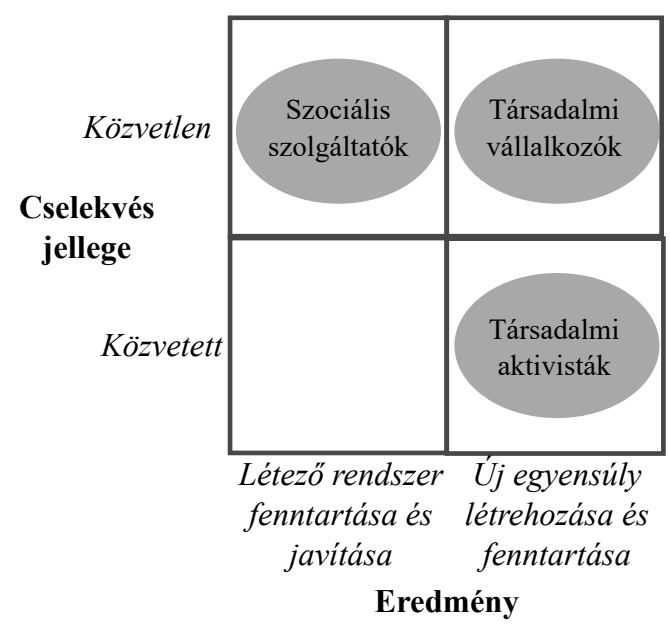

Forrás: Martin \& Osberg $(2007,39)$

A társadalmi vállalkozók számosságát tekintve elmondható, hogy a társadalmi vállalkozások öshazájának tartott Nagy-Britanniában 71.000 ilyen vállalkozást tartanak számon, valamint az 5 és fél millió kis- és középvállalkozó ötöde állítja magáról, hogy társadalmilag hasznos is a tevékenysége. Magyarországon a definíciónak megfelelő, valódi társadalmi vállalkozások száma 100-200 közé tehető, amely lehetne akár 1500 is, amennyiben hozzászámoljuk a szociális szövetkezeteket, azonban utóbbiak sajnos többnyire csak egy-egy pályázat kapcsán jelennek meg, s a projekt kifutását követően el is tünnek (Harsányi - Lévai 2017). Hazai társadalmi vállalkozásra példa a Matyodesign, amely a matyó kultúra motívumaival díszített ruhákat és kiegészítőket értékesít. A termékek hímzését a Borsod-Abaúj-Zemplén megyei Tard asszonyai végzik, fizetésüket pedig a termékek értékesítéséből fedezi a társadalmi vállalkozás.

A fejezetben részletesen bemutatásra kerültek a társadalmi vállalkozók, illetve vállalkozások jellemzői, amely alapján körvonalazódott, hogy az ehhez kapcsolódó attitüd mérésének három blokkja alakítható ki: vállalkozóiság, vállalkozói attitüd, társadalmi érzékenység és a CSR attitüd. A következőkben a társadalmi vállalkozói attitűd méréséhez használandó kérdőív kialakításának menetét mutatjuk be.

\section{ANYAG ÉS MÓDSZER}

Jelen tanulmány célja a társadalmi vállalkozói attitűd mérésére alkalmas kérdőív kidolgozása szekunder kutatás segítségével, amely a három fö kérdésblokk (vállalkozói attitüd, társadalmi vagy szociális érzékenység, CSR attitűd) esetében alkalmazott, illetve már validált skálák feltárását és integrálását foglalja magában. A bemutatott lehetöségek mentén ezt követően pedig a későbbi lekérdezések eszközéül szolgáló kérdőívet ismertetjük.

\section{EREDMÉNYEK - KÉRDŐÍV A TÁRSADALMI VÁLLALKOZÓI ATTITÜD MÉRÉSÉRE}

A társadalmi vállalkozói attitűd mérésére jelenleg nincs nemzetközileg elismert, a gyakorlatban alkalmazott kérdéssor. Az irodalomkutatás során körvonalazódott az a három fö terület, amelynek mérésével közelíthető a társadalmi vállalkozói attitüd, illetve annak erőssége, milyensége is, vagyis a különbözö csoportok, klaszterek azonosítása is lehetővé válik az 1 . ábrabeli vállalkozói spektrumon. A következőkben bemutatjuk az egyes kérdésblokkok tartalmát, indoklását, majd az ezek mentén összeállított végső kérdőivet. 


\section{A vállalkozói attitüd mérésére szolgáló kérdésblokk}

A tervezett kérdőív első kérdésblokkja a vállalkozói attitűd meglétét hivatott mérni. A szakirodalom relatíve gazdag az e célt szolgáló validált mérési skálákat tekintve. Robinson et al. (1991) Entrepreneurial Attitude Orientation (EAO) skálája 1-10-ig terjedő Likert skálán méri a 75 állítással való egyetértés vagy egyet nem értés mentén az innováció, a vállalkozói függetlenség, a teljesítmény utáni vágy és az önbecsülés alskálákat, valamint az attitűdöt. A skálát egyetemi hallgatók, vállalkozók és „nem vállalkozó" csoportok segítségével validálták. Jelen formájában a kérdőív használata kérdéses lehet, hiszen csupán egyetlen blokknak rendkívül hosszú, azonban az eredeti kérdőívnek létezik egy rövidebb 11 kérdéses verziója, amely még kellően robosztus. Bolton és Lane (2012) az egyéni vállalkozói orientációt (Individual entrepreneurial orientation, IEO) méri a kockázatvállalás, az innováció, valamint a proaktivitás mentén. Az egyetemi hallgatókkal validált, korábbi EO skálák továbbgondolásával összeállt kérdéssor 10 állítást tartalmaz, amelyekkel való egyetértést 1-5-ig terjedő skálán tudták kifejezni a válaszadók. Cardon et al. (2013) vállalkozói identitást, szenvedélyt méri a feltalálás (új piaci lehetöségek nyomon követése, új termékek fejlesztése), alapítás (szükséges pénzügyi, humán és egyéb erőforrások megszerzése) és fejlesztés (növekedés és terjeszkedés) dimenziók segítségével. A vállalkozók segítségével validált végső kérdőív 13 állítást mér 1-5-ig terjedő Likert skálán.

A hazai szerzők közül Szakács és tsai (2003) rendkívül komplex vizsgálatot alkalmazva elemzik a vállalkozói személyiséget, feladatokat és különböző területek mérését szolgáló kérdoíveket kombináltak, amelyek eredményeként négy faktort (vállalkozói alkalmasság, függetlenség, szervezői teljesítmény és belső kontroll) határoztak meg, amelyek mérése túlságosan komplex lenne a tervezett kérdőív esetében. Farkas és S. Gubik (2013) a GUESSS (Global University Entrepreneurial Spirit Students' Survey) nemzetközi kutatási projekt kérdőívét alkalmazta, amely az egyetemi hallgatók vállalkozásindítással kapcsolatos elképzeléseit és vállalkozási tevékenységét méri. A kutatás négy kérdéscsoport köré szervezödik (vállalkozási szándék, attitüdök, szubjektív normák, észlelt magatartási kontroll), s ezek tizenhat kérdéscsoportja többségében zárt kérdéseket tartalmaz, alternatívakat és szelektíveket egyaránt. A kérdöív tehát az előzőektől eltérően nem kizárólag Likert-skálán mért állításokkal való egyetértést tartalmaz.
A fentiek alapján a legvonzóbb GUESSS kérdőív lenne, azonban ennek terjedelme túlságosan hosszú, hasonlóan az eredeti EAO skálához, ezért a terület méréséhez az IEO skálát fogjuk használni, amely hasonlóan a GUESSS-hez alapvetően hallgatókra vonatkozik és méri azokat a vállalkozói kulcsterületeket, amelyek a társadalmi vállalkozó személyiségjegyei alapján fontosak, azaz a kockázatvállalást, az innovációt, valamint a proaktivitást. Ennek megfelelően a tervezett kérdőív első vállalkozói attitüd blokkja az alábbi állításokat (1. táblázat) fogja tartalmazni, amellyel való egyetértést 1-5-ig terjedő skálán fejezhető ki.

\section{A társadalmi érzékenység mérésére szolgáló kérdésblokk}

A következő kérdéscsoporttal a válaszadók egyéni társadalmi érzékenységét kívánjuk mérni, hiszen az induló vagy friss vállalkozások esetében az egyén szociális érzékenysége lesz a mérvadó, nem a szervezeté. A társadalmi érzékenység számos formát ölthet. Egyrészt fokozott érdeklődést jelent a mindennapi hazai és nemzetközi események, folyamatok, a politikai-gazdasági-társadalmi szféra változásai, problémai és kihívásai iránt, másrészt érzékenységet mutat a hátrányos helyzetủek, a kisebbség irányában. Ugyanakkor esetünkben különösen fontos, hogy a társadalmi érzékenység tettekben is kifejeződjön, hiszen a társadalmi vállalkozók közvetlenül, aktivitásukon keresztül igyekeznek hatni és céljukat elérni.

A szakirodalmat áttekintve pontos definíciót sem, és így értelemszerủen validált skálát sem találtunk a társadalmi érzékenységre. Ugyanakkor fontosnak tartjuk e tényező vizsgálatát, mivel véleményünk szerint meghatározó részét képezi a társadalmi vállalkozói attitűdnek. Két skála kérdéseinek integrálása mellett döntöttünk a társadalmi érzékenység mérésére.

Az egyik Meijer és Schuyt (2005) által használt és újravalidált skála. Munkájuk a Paul et al. (1997) által fejlesztett és validált skálán alapszik, mely eredetileg az amerikai fogyasztók érzékenységét mérte a vállalati társadalmi teljesítményt (corporate social performance - CSP) illetően. A CSP multidimenzionális „felépítmény”, melyben négy fö területen összegződnek a vállalat kezdeményezései: természeti környezet (például környezetbarát termékek), az alkalmazottakkal való bánásmód (például profitmegosztás), a munkahelyek diverzitása (például nemek, szexuális-orientáció alapú diverzitás) és a vevő és termék biztonsága (Berman et al. 1999). 


\section{1. táblázat: A tervezett kérdőív vállalkozói attitűdre vonatkozó kérdései}

\begin{tabular}{|l|l|}
\hline RISK1 & Szeretek merészen belépni az ismeretlenbe. \\
\hline RISK2 & $\begin{array}{l}\text { Hajlandó vagyok sok időt és/vagy pénzt fektetni olyan dolgokba, amelyek magas } \\
\text { haszonnal kecsegtetnek. }\end{array}$ \\
\hline RISK3 & Hajlamos vagyok bátran cselekedni kockázatos helyzetekben. \\
\hline INNOV1 & $\begin{array}{l}\text { Gyakran szeretek kipróbálni új és szokatlan dolgokat, amelyek nem jellemzöek rám, } \\
\text { de nem feltétlenül kockázatosak. }\end{array}$ \\
\hline INNOV2 & $\begin{array}{l}\text { Általában inkább azokat a projekteket szeretem, amelyek nagy hangsúlyt fektetnek az } \\
\text { egyedülálló, újfajta megközelítésekre, mint azokat, amelyek már kipróbált és bizonyított } \\
\text { megközelítéseket igényelnek. }\end{array}$ \\
\hline INNOV3 & $\begin{array}{l}\text { Amikor új dolgokat tanulok, jobban szeretem azokat kipróbálni a magam módján, mint- } \\
\text { sem úgy, ahogyan mindenki más. }\end{array}$ \\
\hline INNOV4 & $\begin{array}{l}\text { A problémamegoldás során inkább a kísérletezést és az eredeti megoldásokat szeretem } \\
\text { alkalmazni, mint e probléma megoldására az általában mások által használt vagy bevált } \\
\text { módszereket. }\end{array}$ \\
\hline PROACT1 & $\begin{array}{l}\text { Általában a jövőbeli problémák, szükségletek vagy változások figyelembevételével } \\
\text { cselekszem. }\end{array}$ \\
\hline PROACT2 & Hajlandó vagyok elöre tervezni a projektek esetében. \\
\hline PROACT3 & $\begin{array}{l}\text { Inkább szeretek cselekedni, amikor kell, hogy haladjon a projekt, mint ülni és várni, } \\
\text { hogy valaki más megcsinálja az adott dolgot. }\end{array}$ \\
\hline
\end{tabular}

Forrás: saját szerkesztés Bolton-Lane (2012) alapján

A skála validálását újból elvégezte Meijer és Schuyt (2005) holland fogyasztók bevonásával. Vizsgálatukban támaszkodtak azokra a korábbi vizsgálati eredményekre is, melyek különböző társadalmi, demográfiai jellemzők hatását vizsgálták a környezeti problémákkal szembeni érzékenységre. Kutatási eredményük igazolta a CSP skála megbízhatóságát és nyugat-európai országokban való alkalmazhatóságát. Vizsgálatuk eredménye alapján a holland fogyasztók számára a vállalati társadalmi teljesítmény elvárt minimum, mintsem motivációs tényező vásárlásaikkor. A társadalmi demográfiai jellemzők közül a politikai hovatartozás, az iskola végzettség, a kor és nem befolyásolja a társadalmi teljesítménnyel kapcsolatos érzékenységet (Meier \& Schuyt 2005).

Korábbi kutatások (Abdul Rashid \& Abdullah 1991, Kinard et al. 2003, Owen \& Scherer 1993) a menedzsment attitűdjét vizsgálták a társadalmi teljesítménnyel szemben. A társadalmi vállalkozóknál azonban fontos, hogy jellemzően induláskor még nem irányítanak klasszikus üzleti szervezetet, másrészt ők cselekedeteiken keresztül igyekeznek hatni és céljukat elérni, így célszerübbnek láttuk az érzékenységüket megragadni fogyasztói mivol- tukban. A Meijer és Schuyt (2005) által validált fogyasztói érzékenység skála kérdései pedig épp arra fókuszálnak, hogy a fogyasztók aktivitását, történetesen a vásárlásukat mennyire befolyásolja a terméket, szolgáltatást előállító cég társadalmi teljesítménye.

A másik skála Pekaar et al. (2018) által validált érzelmi intelligencia skála (Rotterdam Emotional Intelligence Scale - REIS), pontosabban annak néhány kérdése. Az érzelmi intelligencia mérésével és az üzleti világgal való kapcsolatával több szakirodalmi munka foglalkozik. Ezelyek alapján az üzleti világ szereplőinek érzelmi intelligenciája és teljesítménye között a kapcsolódás több szinten is egyértelmủ (vezetői kiválóság, vállalkozásalapítás) (Wong \& Law 2012, Lindebaum \& Cartwright 2010, Altindaga \& Kösedagia 2015, FakhrEldin 2017). A társadalmi vállalkozók vizsgálatakor a skála azon kérdéseit használjuk, melyek mások érzéseinek felismerésére, az empátiára vonatkoznak.

Ennek megfelelően a tervezett kérdőív második, társadalmi érzékenységet mérő az alábbi állításokat (2. táblázat) fogja tartalmazni, amellyel való egyetértést 1-5-ig terjedő skálán fejezhető ki. 


\section{2. táblázat: A tervezett kérdőív társadalmi érzékenységre vonatkozó kérdései}

\begin{tabular}{|l|l|}
\hline SENS1 & $\begin{array}{l}\text { Hajlandó lennék kicsivel többet fizetni olyan vállalat termékért, amely példamutató } \\
\text { a nök támogatásában és alkalmazásában. }\end{array}$ \\
\hline SENS2 & $\begin{array}{l}\text { Hajlandó lennék kicsivel többet fizetni olyan vállalat termékért, amely aktívan tesz } \\
\text { a környezetért. }\end{array}$ \\
\hline SENS3 & Nem fektetnék be olyan cégbe, amelynek társadalmi felelösségvállalása elégtelen. \\
\hline SENS4 & Bojkottálom azokat a vállalatokat, amelyek nem vállalnak társadalmi felelösséget. \\
\hline SENS5 & $\begin{array}{l}\text { Igyekszem elkerülni azon termékek megvásárlását, amelyek gyártóinak társadalmi } \\
\text { felelösségvállalása elégtelen. }\end{array}$ \\
\hline SENS6 & $\begin{array}{l}\text { Hajlandó lennék kicsivel többet fizetni olyan vállalat termékért, amely példamutató az } \\
\text { etnikai kisebbség támogatásában és alkalmazásában. }\end{array}$ \\
\hline SENS7 & $\begin{array}{l}\text { Zavarna, ha olyan vállalat alkalmazásában állnék, amelynek társadalmi felelósségválla- } \\
\text { lása elégtelen. }\end{array}$ \\
\hline SENS8 & $\begin{array}{l}\text { Hajlandó lennék kicsivel többet fizetni olyan vállalat termékért, amelynek reklámja nem } \\
\text { támogatja az eröszakot. }\end{array}$ \\
\hline SENS9 & $\begin{array}{l}\text { Hajlandó lennék kicsivel többet fizetni olyan vállalat termékért, amely nem használ állat- } \\
\text { kíreteteket termékfejlesztéséhez. }\end{array}$ \\
\hline SENS10 & Dühít, ha a vállalatok társadalmilag felelötlenek. \\
\hline SENS11 & $\begin{array}{l}\text { Hajlandó lennék kicsivel többet fizetni olyan vállalat termékért, amely inkább új munka- } \\
\text { helyeket teremt, mintsem leépít. }\end{array}$ \\
\hline EI1 & Tudatásban vagyok a körülöttem levö emberek érzelmeinek. \\
\hline EI2 & Tudom milyen érzelmeket tapasztalnak mások. \\
\hline EI3 & Ha ránézek másokra, látom, hogyan éreznek. \\
\hline EI4 & Képes vagyok empatikus lenni a körülöttem levő emberekkel. \\
\hline EI5 & Megértem, hogy más emberek miért éppen úgy éreznek, ahogy. \\
\hline EI6 & Képes vagyok megkülönböztetni más emberek érzelmeit. \\
\hline EI7 & Képes vagy jól megítélni, ha bizonyos helyzetek valakit érzelmileg megérintenek. \\
\hline
\end{tabular}

Forrás: saját szerkesztés Meijer - Schuyt (2005) és Pekaar et al. (2018) alapján

\section{A CSR attitüd mérésére szolgáló kérdésblokk}

Az utolsó kérdéscsoport a CSR attitűd mérését szolgálja. Az egyik cél annak vizsgálata, hogy vajon az első két blokk eredményeivel összhangban megjelenik-e magas vállalkozói attitűd és társadalmi érzékenység esetén a CSR iránti elköteleződés is, másrészt e blokk azt is megmutatja, hogy szervezetben való gondolkodás esetén mennyire érvényesülnek a szociális szempontok. A CSR attitüd mérésére vagy nagyon komplex megoldások léteznek, vagy pedig a CSR egy-egy szeletére fókuszálnak, mint például Lock és Seele (2017) egészen friss PERCRED (Perceived Credi- bility) skálája, amely a CSR jelentések, illetve CSR kommunikáció hitelességének megítélését méri. A komplex mutatók mérik az olyan dimenziókat, mint a CSR folyamat, irányelvek vagy vállalatirányítás, értékek, a környezet, a személyes beállítódás, a profit, az érintettek és a politika (lásd például Mahoney \& Thorne 2005, Toliver 2013). Egy több területet mérő, kellően komplex, ám kezelhetô állításszámmal bíró skála a nemzetközi irodalomban is gyakran alkalmazott a 2009ben Turker által publikált CSR skála. A 18 állítást tartalmazó, érintett elméleten alapuló - a négy mért érintett csoport a társadalom, az alkalmazottak, a fogyasztók és az állam - kérdéssort adaptáljuk a tervezett utolsó nagyobb témakör mérésére (3. táblázat). 


\section{3. táblázat: A tervezett kérdőív vállalkozói CSR attitúdre vonatkozó kérdései}

\begin{tabular}{|c|c|}
\hline SOC1 & $\begin{array}{l}\text { A vállalatoknak részt kell vennie olyan tevékenységekben, amelyek célja a környezet } \\
\text { állapotának megóvása és javítása. }\end{array}$ \\
\hline SOC2 & $\begin{array}{l}\text { A vállalatok olyan beruházásokat kell folytassanak, amelyek jobbá teszik a jövő generá- } \\
\text { ciók életét. }\end{array}$ \\
\hline SOC3 & $\begin{array}{l}\text { A vállalatoknak olyan speciális programokat kellene megvalósítania, amelyekkel mini- } \\
\text { malizálják környezetre gyakorolt negatív hatásukat. }\end{array}$ \\
\hline SOC4 & $\begin{array}{l}\text { A vállalatok célja a fenntartható növekedés kell legyen, amely figyelembe veszi a jövő } \\
\text { generációit is. }\end{array}$ \\
\hline SOC5 & $\begin{array}{l}\text { A vállalatok támogassanak olyan nem állami szervezeteket, amelyek valamilyen fontos } \\
\text { probléma megoldásán dolgoznak. }\end{array}$ \\
\hline SOC6 & $\begin{array}{l}\text { A vállalatok vegyenek részt olyan kampányokban és projektekben, amelyek elösegítik a } \\
\text { társadalom jólétét. }\end{array}$ \\
\hline SOC7 & A vállalatoknak bátorítani kell az alkalmazottaikat, hogy önkénteskedjenek. \\
\hline $\begin{array}{l}\text { SOC8, } \\
\text { CUST1 }\end{array}$ & A vállalatoknak hangsúlyoznia kell a társadalmi felelősség fontosságát. \\
\hline EMP1 & $\begin{array}{l}\text { A vállalatpolitikának lehetővé kell tennie az alkalmazottak számára, hogy fejlesszék } \\
\text { képességeiket és építsék karrierjüket. }\end{array}$ \\
\hline EMP2 & $\begin{array}{l}\text { A vállalatok vezetősége első sorban alkalmazottai szükségleteivel és igényeivel } \\
\text { foglalkozzon. }\end{array}$ \\
\hline EMP3 & $\begin{array}{l}\text { A vállalatok tegyenek lehetővé olyan rugalmas megoldásokat, amelyek jó munka- } \\
\text { magánéletközti egyensúlyt tesznek lehetővé a dolgozók számára. }\end{array}$ \\
\hline EMP4 & A munkavállalókkal kapcsolatos vezetői döntések legyenek tisztességesek. \\
\hline EMP5 & $\begin{array}{l}\text { Cégek támogassák azokat a dolgozóikat, akik további oktatásban, képzésben szeretnének } \\
\text { részesülni. }\end{array}$ \\
\hline CUST2 & Vállalatok tartsák tiszteletben a fogyasztói jogokat a törvényben elöírtakon túlmenően is. \\
\hline CUST3 & Cégek nyújtsanak teljes körü és pontos információkat a termékeikröl a vásárlók számára. \\
\hline CUST4 & A fogyasztói elégedettség legyen kiemelten fontos egy vállalat számára. \\
\hline GOV1 & A vállalatok rendszeresen fizessenek adót. \\
\hline GOV2 & $\begin{array}{l}\text { A vállalatok a törvények életbelépést követően azonnal és teljes körúen feleljenek meg } \\
\text { azoknak (ne keressenek kiskaput, ne éljenek az esetleges türelmi idővel). }\end{array}$ \\
\hline
\end{tabular}

Forrás: saját szerkesztés Turker (2009) alapján 


\section{ÖSSZEFOGLALÁS}

Tanulmányunk a társadalmi vállalkozó fogalmi rendszerének tisztázása mellett a társadalmi vállalkozói attitüd mérésére fókuszált. A mérésre alkalmas kérdőív kidolgozása szakirodalmi források feldolgozására támaszkodott, három fő aspektus - a vállalkozói attitüd, a társadalmi érzékenység és a CSR attitűd - mérésére használt, validált skálák integrálásával. A kutatás következő (a tanulmány írásakor zajló) fázisában a minta összeállítása, az adatfelvétel helyszínének és módjának tesztelése történik a kérdőív próbakérdezésével párhuzamosan. Célunk a létrehozott skála validálása, annak vizsgálata, hogy a három fö blokk mindegyike valóban jó közelítéssel méri a társadalmi vállalkozói attitüdöt. E kérdés különösképpen érdekes és fontos a második blokk, a társadalmi érzékenység esetében, hiszen ez egyrészt két skálát integrál, másrészt az eredeti skálákat fogyasztói mintán validálták.

Kutatásunk hazai és nemzetközi szinten is hiánypótló, eredményei alapját adják további kutatásoknak a társadalmi vállalkozások mélyebb megértése céljából.

\section{HIVATKOZÁSOK}

Abdul Rashid, M. Z., Abdullah, I. (1991), 'Executive and management attitudes towards corporate social responsibility in Malaysia", Corporate Governance, 2 4, 10-6 DOI: https://doi. org/10.1108/14720700210447641

Abu-Saifan, S. (2012), "Social Entrepreneurship: Definition and Boundaries", Technology Innovation Management Review, 2 2, 22-7 DOI: https://doi.org/10.22215/timreview523

Agafonow, A. (2014), "Toward A Positive Theory of Social Entrepreneurship. On Maximizing versus Satisficing Value Capture", Journal of Business Ethics. 125 4, 709-13 DOI: https://doi. org/10.1007/s10551-013-1948-z

Altındaga, E., Kösedagia, J. (2015), "The Relationship between Emotional Intelligence of Managers, Innovative Corporate Culture and Employee Performance", Social and Behavioral Sciences, 210, 270-82 DOI: https://doi. org/10.1016/j.sbspro.2015.11.367

Basdekidou, V. A. (2017), "Green Entrepreneurship \& Corporate Social Responsibility: Comparative and Correlative Performance Analysis", International Journal of Economics and Finance, 9 12, 1-12. DOI: https://doi. org/10.5539/ijef.v9n12p1

Berman, S. L., Wicks, A. C., Kostha, S., Jones, T. M. (1999), "Does stakeholder orientation matter? The relationship between stakeholder management models and firm financial performance", Academy of Management Journal, 42 5, 488506 DOI: https://doi.org/10.5465/256972

Bolton, D. L., Lane, M. D. (2012), 'Individual entrepreneurial orientation: development of a measurement instrument", Education + Training, 54 2/3, 219-33 DOI: https://doi. org/10.1108/00400911211210314

Cardon, M. S., Gregoire, D. A., Stevens, C. E., Patel, P. C. (2013), "Measuring entrepreneurial passion: Conceptual foundations and scale validation", Journal of Business Venturing, 28 3, 373-96 DOI: https://doi.org/10.1016/j. jbusvent.2012.03.003

Chell, E. (2007), "Social Enterprise and Entrepreneurship Towards a Convergent Theory of the Entrepreneurial Process", International Small Business Journal, 25 1, 3-19 DOI: https://doi. org/10.1177/0266242607071779

Chell, E., Nicolopoulou, K., Karatas-Ozkan, M. (2010), "Social Entrepreneurship: Innovation and Cross-Cultural Aspects", Entrepreneurship and Regional Development, 22 6, 485-94 
DOI: https://doi.org/10.1007/978-1-4614-3858$8 \_100205$

Cheney, G., Roper, J. (2005), "The meanings of social entrepreneurship today", Corporate Governance: International Journal of Business in Society, 5 3, 95-104. DOI: https://doi. org/10.1108/14720700510604733

Cholette, S., Kleinrichert, D., Roeder, T., Sugiyama, K. (2014), "Emerging Social Entrepreneurial CSR Initiatives in Supply Chains", The Journal of Corporate Citizenship, 55, 40-72 DOI: https://doi.org/10.9774/gleaf.4700.2014. se. 00007

Dees, J. G. (1998), "The Meaning of "Social Entrepreneurship"', https://pullias.usc.edu/ wp-content/uploads/2012/06/dees.pdf Letöltve: 2019.07.19.

Di Domenico, M., Haugh, H., Tracey, P. (2010), "Social Bricolage: Theorizing Social Value Creation in Social Enterprises", Entrepreneurship Theory and Practice, 34 4, 681-703 DOI: https:// doi.org/10.1111/j.1540-6520.2010.00370.x

Európai Bizottság (2011), „Social enterprises”, http://ec.europa.eu/growth/sectors/social-economy/enterprises_hu Letöltve: 2019.07.19.

Farkas Sz. - S. Gubik A. (2013), „Az egyetemi-föiskolai hallgatók vállalkozói attitűdkutatásának módszertani sajátosságai”, Statisztikai Szemle, 91 10, 993-1012

FakhrEldin, H. (2017), "The relationship between the emotional intelligence of entrepreneurs and the new venture creation: The role of age, gender and motive", Arab Economic and Business Journal, 12 2, 99-108 DOI: https://doi. org/10.1016/j.aebj.2017.10.002

Harsányi A. - Lévai G. (2017), „Társadalmi jót üzleti alapon”, https://vs.hu/gazdasag/osszes/ tarsadalmi-jot-uzleti-alapon-0227\#!s1 Letöltve: 2019.07.19.

Kinard, J., Smith, M. E., Kinard, B. R. (2003), "Business executives'attitudes toward social responsibility: Past and present", American Business Review, 21 2, 87-91

Lindebaum, D., Cartwright, S. (2010), "A critical examination of the relationship between emotional intelligence and transformational leadership", Journal of Management Studies, 47 1317-42 DOI: https://doi.org/10.1111/j.14676486.2010.00933.x

Lock, I., Seele, P. (2017), "Measuring Credibility Perceptions in CSR Communication: A Scale Development to Test Readers' Perceived Credibility of CSR Reports", Management Cоттиnication Quarterly, 31 4, 584-613. DOI: https:// doi.org/10.1177/0893318917707592
Lukács R. (2015), „A vállalati reputáció és a vállalatok társadalmi felelősségvállalása érintetti szempontból - kvalitatív kutatás egy bevásárolóközösségben", Marketing és Menedzsment, 49 4, 3-17

Mahoney, L. S., Thorne, L. (2005), "Corporate social responsibility and long-term compensation: Evidence from Canada", Journal of Business Ethics, 57 3, 241-53 DOI: https://doi. org/10.1007/s10551-004-5367-z

Martin, R. L., Osberg, S. (2007), "Social Entrepreneurship: The Case for Definition", Stanford Social Innovation Review, Spring, 29-39

Meijer M., Schuyt T. (2005), "Corporate Social Performance as a Bottom Line for Consumers", Business \& Society, 44 4, 442-6 DOI: https:// doi.org/10.1177/0007650305281659

Nicolopoulou, K. (2014), ”Social Entrepreneurship between Cross-Currents: Toward a Framework for Theoretical Restructuring of the Field", Journal of Small Business Management, 52 4, 678-702 DOI: https://doi.org/10.1111/ jsbm. 12130

Owen, C. L., Scherer, R. F. (1993), "Social responsibility and market share", Review of Business, $15,11-6$

Paul, K., Zalka, L. M., Downes, M., Perry, S., Friday, S. (1997), "U.S. consumer sensitivity to corporate social performance", Business \& Society, 36 4, 408-18 DOI: https://doi. org/10.1177/000765039703600405

Pekaar, K. A., Bakker, A. B., van der Linden, D., Born, M. (2018), "Self- and other-focused emotional intelligence: Development and validation of the Rotterdam Emotional Intelligence Scale (REIS)", Personality and Individual Differences, 120, 222-33 DOI: https://doi. org/10.1016/j.paid.2017.08.045

Piskóti I. (2012), „Elemek a társadalmi marketing modelljéhez", Marketing és Menedzsment, 46 3, 64-73

Putzer P. - Csapi V. (2018), „Mire jó a CSR?: Hazai vállalati csoportok a felelösség mentén és reálopciós elemzésük", Marketing és Menedzsment, 52 EMOK Különszám, 10-18

Robinson, P. B., Stimpson, D. V., Huefner, J. C., Hunt, H. K. (1991), "An Attitude Approach to the Prediction of Entrepreneurship", Entrepreneurship Theory and Practice, 15 4, 13-32 DOI: https://doi.org/10.1177/104225879101500405

Szakács F. - Bánfalvi M. - Nagy I. - Veres N. Karcsics É. (2003), „A vállalkozói személyiség", in G. Márkus Gy. (szerk.), Tudományos Közlemények 9. - Európaizáció, Globalizáció, Reformok, Budapest: Általános Vállalkozási 
Főiskola, 15-70

Thompson, J. L. (2002), "The World of the Social Entrepreneur", The International Journal of Public Sector Management, 15 5, 412-431 DOI: https://doi.org/10.4337/9781843765639.00023

Timár G. (2014), „A sikeres társadalmi vállalkozás receptje", Piac és Profit, http://www.piacesprofit.hu/kkv_cegblog/a-sikeres-tarsadalmi-vallalkozas-receptje/ Letöltve: 2019.07.19.

Toliver, A. D. (2013), Measuring Corporate Social Responsibility Through Organizational Values: a Scale Validation Study, The University of Texas at Arlington: PhD Dissertation
Turker, D. (2009), "Measuring Corporate Social Responsibility: A Scale Development Study", Journal of Business Ethics, 85 4, 411-27 DOI: https://doi.org/10.1007/s10551-008-9780-6

Wong, C. S. and Law, K.S. (2002), "The effects of leader and follower emotional intelligence on performance and attitude: An exploratory study", The Leadership Quarterly, 13 3, 243-74 DOI: https://doi.org/10.1016/s10489843(02)00099-1

Putzer Petra PhD, egyetemi adjunktus putzerp@ktk.pte.hu

Bányai Edit $\mathrm{PhD}$, egyetemi docens banyai.edit@ktk.pte.hu

Pécsi Tudományegyetem Közgazdságtudományi kar

\section{Social entrepreneur as possible future of CSR and measuring social entrepreneurial attitude}

\section{THE AIMS OF THE PAPER}

CSR is becoming more and more popular and fashionable nowadays, but in many cases the responsible actions or activities are not about serving the social good; these are just simply new marketing tools for companies. At the same time, with the emergence of social entrepreneurs, a possible new vision for the real responsibility seems to emerge. The aim of the study is to present the concept of a social entrepreneur(ship) and to interpret it in the framework of CSR, and based on these to develop a tool for measuring social entrepreneurial attitude.

\section{METHODOLOGY}

According to the conceptual clarification and the analysis of social enterprises in the entrepreneurial spectrum, we determine what aspects of the social entrepreneurial attitude should be taken into consideration. A questionnaire, which is suitable for measuring social entrepreneurial attitude, is developed using secondary research. We explored and integrated applied and validated scales for measuring the three main question blocks (entrepreneurial attitudes, social sensitivity, and CSR attitudes).

\section{MOST IMPORTANT RESULTS}

The results give the impression that the new generation of entrepreneurs can save the CSR concept but there was not a validate scale. Therefore to measure this entrepreneurial attitude a possible questionnaire was developed as a result. The aim is to use and validate this questionnaire if it is a suitable research tool with the three blocks to explore social entrepreneurial attitude primarily among university students.

\section{RECOMMENDATIONS}

Our research has relevant importance both at domestic and international level, our results is going to give the basis and implication for further research connected to deeper analysis and understanding of social enterprises. As a next step we have started to test this questionnaire.

Keywords: social entrepreneur, entrepreneurial attitude, social sensitivity, CSR attitude 